$\mathrm{A} \int_{\cos } \mathrm{H}$

Article history :

Received : 21.02.2015

Revised : 05.04.2015

Accepted : 09.05.2015
Members of the Research Forum

Associated Authors:

${ }^{1}$ Horticultural Research Station (TNAU) OOTY (T.N.) INDIA
Author for correspondence : V.P.SANTHI

Horticultural Research Station (TNAU) OOTY (T.N.) INDIA

Email : santhihortvip@yahoo.co.uk
THEASIAN JOURNAL OF HORTICULTURE

Volume 10 | Issue 1 | June, 2015 | 100-104

Visit us -www.researchjournal.co.in

\title{
Evaluation of french beans ( Phaseolus vulgaris L.) bush type at mid and higher elevations of Nilgiris
}

\section{P. SANTHI, P. RAJA ${ }^{1}$, B. ANITA ${ }^{1}$ AND N. SELVARAJ ${ }^{1}$}

ABSTRACT : Ten accessions of traditional french beans - types were collected from different elevations and evaluated for yield and quality at Nanjanad Farm, HRS, Ooty. The 10 entries of bush beans were evaluated in a Randomized Block Design with 3 replications at Nanjanadu Farm, HRS, Ooty. Observations were taken on growth and yield characters from 2010 onwards. Observation on plant height, number of branches, number of compound leaves, days taken of flowering, number of pods, days taken for pod setting, pod length, pod diameter and pod weight per plant were recorded. As indicated in the pooled means of four years from 2010 to 2013, among the bush bean types, accession number FBB-7 (Aruvath avarai) has recorded highest pod yield of $712.73 \mathrm{~g} / \mathrm{plant}$ and pod weight of $15.80 \mathrm{~g} /$ pod. The highest genotypic coefficient of variation was observed for number of leaves, pod weight and yield. High heritability values were observed in plant height, number of branches, number of leaves, days for flowering and pod development, pod length, pod diameter, pod weight and yield. The expected genetic advance expressed as percentage of mean was relatively high for the characters viz., plant height, branch, number of leaves, days for flowering, days for pod development, pod length, pod diameter, pod weight and yield.

KEY WORDS : Growth, Yield, genotypic co-efficient of variation, Heritability, Genetic advance

HOW TO CITE THIS ARTIClE : Santhi, V.P., Raja, P., Anita, B. and Selvaraj, N. (2015). Evaluation of french beans ( Phaseolus vulgaris L.) bush type at mid and higher elevations of Nilgiris. Asian J. Hort., 10(1) : 100-104. 